\title{
Recent Changes in Korea's Business Environment: Views of Foreign Business People in Korea
}

\author{
Professor O. Yul Kwon Ph.D \\ Griffith Business School \\ Griffith University \\ Brisbane, Queensland 4111 \\ AUSTRALIA \\ Tel: (617) 3875-7072 \\ Fax: (617) 3875-5173 \\ Email: Y.Kwon@griffith.edu.au
}

Exact length of the article: 6520 words plus 7 tables (1071 words)

Biographical Description of the author: Professor O. Yul Kwon, the Korea Foundation Chair in Korean Studies and the Director of the Australian Centre for Korean Studies at Griffith University, has published a number of books and articles in refereed journals and chapters of books on the Korean economy and business. 


\title{
Changes in Korea's Business Environment: Views of Foreign Business People in Korea
}

\begin{abstract}
(Abstract)
The paper attempts to assess changes in the Korean business environment after the 1997 financial crisis from a foreign perspective. To this end, a comprehensive survey has been conducted of foreign business people in Korea. Although Korea has undertaken various policy measures and all-out efforts to improve its business environment in the recent past, the present study shows that foreign business people have in general a negative view on the progress. It further shows that there is substantial room for improvement in numerous areas. Not only should excessive government regulations and bureaucratic power be removed, but unfair advantages bestowed on domestic firms, inflexibility in the labour market, and living conditions of foreign expatriates should also be improved. Korean people need to become more open and amicable to foreigners and foreign business operations in Korea.
\end{abstract}

Key words: Survey; foreigners’ view; business environment; Korea

\section{Introduction}

Prior to the 1997 financial crisis, foreigners regarded South Korea (hereafter Korea) as one of the most difficult places to do business (Booz.Allen \& Hamilton 1997:28; Far Eastern Economic Review 1998). In implementing its government-led development strategy, the government intervened extensively in the economy with a plethora of rules and regulations. As part of its industrialisation policy, the government protected domestic industries from international competition by restricting imports and inward foreign direct investment (FDI). This eventually rendered domestic industries inept at adapting themselves to the changing business environment and created inefficiency, resulting in a significant loss of losing international competitiveness by the mid-1990s. Korean industrialisation policy also provided chaebols with incentives and protection and encouraged them to expand and diversify excessively with debt capital, generating collusive government-chaebol relationship (Cha 2001; Jwa and Yi 2001; Kwon 1998). 
Government regulations and interference extended to the financial sector and the labour market. To control credit allocation for policy purposes, the Korean government regulated the financial sector and protected it from foreign competition. This generated a collusive relationship between government and banks and a myth that banks were immune from bankruptcy, rendering the financial sector inefficient, under-capitalized and subject to moral hazard. Government intervention and repression of the labour market over time caused labour market inflexibility, which led to greater union militancy and higher wages after the political democratisation in the late 1980s. These characteristics of government policy and the resulting business environment were directly related to the causes of the 1997 financial crisis (Cha 2001; Jwa and Yi 2001; Kwon 2001a).

Since the financial crisis, the Korean government has undertaken a paradigm shift in its economic policy and pursued relentless institutional and structural reforms in compliance with the IMF rescue package (Bishop 2001, Kwon 2001a). Korean economic policy has changed from promoting a government-led economy to a market economy. The government has abandoned its policy of protecting domestic industries, pursued the task of restructuring chaebols, and liberalised the economy, while opening the Korean market widely to international competition through trade, FDI and M\&A. The banking sector has been reformed and exposed to greater foreign competition. Reforms of chaebols and the financial sector have enhanced transparency and accountability in business operations. The government has also managed to reform labour laws that enhance labour market flexibility.

It has also been argued that even Korean society and its people have changed, becoming more amicable to foreign business operations in Korea (Kim and Choo 2002). Through their bitter experiences during the crisis, Koreans have changed their perceptions of foreign business and begun to appreciate its contribution to a stable Korean economy. 
Finally, Korean firms have realised that they can no longer maintain their distinct management system in the face of emerging international competition in an era of globalization. Shim and Steers (2002) strongly argue that a principal reason for the financial crisis was the failure of management to adjust to changing business circumstances. They also warn that unless there is a management revolution, Korean firms may face another crisis in the near future. With the cataclysmic extent of the financial crisis, the IMF requirements for business reform, and the unfavourable comparison of the Korean management system that have frequently been made with the managerial performance of the US, it would be expected that Korean companies have been changing their management towards the western (UK-US) system.

All these developments in Korea's business environment since the crisis will help it discard its now unwanted reputation of being a difficult place for foreigners to do business, and will help establish a new reputation for Korea as an attractive place to do business (Kim 2003; Kim and Choo 2002). However, even though the reforms of formal institutions (rules, regulations, government policy and government-business relations) have been undertaken to the extent of IMF requirements, in view of the path dependency in institutional changes that are argued by institutional economists (North 1990), a serious doubt is cast on the actual extent of change in economic and business behaviour. Whitley (1998) and Beeson (2002) argue that within a more truncated timeframe many of the most important economic indicators related to business environments continue to display distinctly regional or national characteristics instead of shifting to global standards. It is therefore a matter of empirical study to assess the extent of changes in Korea's business environment.

Despite the series of measures undertaken by the Korean government and all-out efforts by Korean society to improve the business environment, there remains little 
convincing evidence that Korea's business environment has actually improved. ${ }^{\mathrm{i}}$ There is a paucity of specific or quantified information on the direction and magnitude of changes in the business environment since the 1997 crisis. Oh and Park (2002) argue that even after the financial crisis, chaebols still retain their unique practices of diversification with debt capital, central decision making, and family ownership and control. Oh and Park (2002) and Cho and Yoon (2002) have also noted that there are no empirical studies that show changes in Korean corporate culture. In mid-1996 Park (2002) attempted to empirically assess changes in corporate cultures in Korea, and concluded that many Korean companies failed in their attempts at changing their corporate cultures despite a great deal of managerial effort to do so. Since Park’s (2002) empirical study was undertaken prior to the crisis, his conclusion of cultural and attitudinal changes could be different from those after the 1997 financial crisis.

In particular, the effectiveness of the measures and efforts undertaken by the Korean government and society has not been evaluated from a foreign perspective. The views of foreign business people who have business experiences in Korea are critically important because it is these people that Korea must convince if the country's image is to undergo real change. However, no systematic research has been undertaken in this area. ${ }^{\text {ii }}$ The objective of this paper is therefore to examine changes in Korea's business environment after the 1997 financial crisis, as they are perceived by foreigners undertaking business operations in Korea.

\section{Methodology}

To assess Korea's business environment and its recent changes from a foreign perspective, a comprehensive survey was conducted from May to July 2002 of foreign companies that had undertaken direct investment in Korea and were operating businesses in Korea. In developing the questionnaire for the survey, it was attempted to include all spheres of 
business environments identified in literature on the international business environment, FDI, management, and human resource management (Bishop 2001; Chang and Chang 1994; Dunning 2000; Hill 2005; Lee 1989; Pearce and Robinson 1994; Rowley 2001). Two forms of questionnaires have been developed. The first questionnaire was comprised of six sections and 70 questions related to various aspects of the business environment. Respondents were questioned on (1) their perception of changes in the Korean business environment after the 1997 financial crisis; (2) their perception of managerial issues arising from their on-site business operations in Korea; (3) their perception of Korean chaebols; (4) their perception of Korean workers; (5) their perception of changes in the Korean management system; and (6) their perceptions of improvements in living conditions for foreign expatriates. The second questionnaire was developed in Korean, and contained 25 questions selected from the first questionnaire. This second questionnaire was intended to identify differences in perception, if any, between foreigners and Korean workers on some specific and important aspects of Korea’s business environment.

The first questionnaire was distributed to about 400 foreign companies in Korea, and 69 of them responded. For the survey, foreign companies in Korea were chosen from the 2002 lists of members of the Chambers of Commerce in Korea of the United States, Canada, Japan, EU, and Australia-New Zealand. After learning that the response rate of sample surveys of foreign companies in Korea is dismally low as they are all inundated with such surveys, random selection of companies was abandoned. It was also learned that the response rates are markedly different by home countries of the foreign companies in Korea. Hence, random sampling of foreign companies in Korea is a futile exercise because, even if companies are selected randomly, there is no assurance that respondents who would actually respond the questionnaire are randomly distributed. It should be noted that 
the response rate to academic questionnaires is notoriously low in Korea. Unless urged by senior managers or through personal connections, staff of Korean companies typically discard unsolicited questionnaires. Hence, the second questionnaire was distributed to senior managers of a number of Korean companies and commercial banks in Korea, asking them to distribute it to their employees. It should thus be noted that neither the number of employees to whom the questionnaire was distributed nor the response rate was provided to the author. From these domestic companies, 217 responses were received.

The present research is an 'exploratory' study with a focus on addressing a research question of what perceptions foreign business people have about the changes in Korean business environment. ${ }^{\mathrm{iii}}$ No attempt has been made to test any hypothesis or to draw causality relationships. Nor has any attempt been made to identify and analyse specific reasons for success or failure in improving the business environment. However, it should be pointed out that, as mentioned above, the survey is quite comprehensive and includes a large number of spheres of the international business environment.

No attempt has been made to conduct validity and reliability tests of the data (responses) because the response to each question is a one-time and one-form measurement. However, various measures have been undertaken to enhance validity and reliability. First, each of the questions in the questionnaire is based on theoretical concepts in literature of the international business environment, Korean management and human resource management, as mentioned above (Bishop 2001; Chang and Chang 1994; Dunning 2000; Hill 2005; Lee 1989; Pearce and Robinson 1994; Rowley 2001). ${ }^{\text {iv }}$ Second, a draft questionnaire was commented on by a number of colleagues, and a pilot survey was conducted with a draft questionnaire that was completed by a number of foreign business people in Korea and Korean workers on a person-to-person basis. Through these processes, the format of the questionnaire was finalised. ${ }^{\mathrm{v}}$ Third, as mentioned above, a 
large number of questions (70 questions), representing all spheres of business environment, was contained in the questionnaire to enhance validity of the data (Neuman 2000: 168). Finally, in order to supplement the survey and garner additional information, personal interviews were conducted with a number of the responding company representatives, some foreign expatriates, and several business executives of Korean companies.

\section{Survey Results}

\subsection{Differences in Perspectives between Foreigners and Koreans}

Respondents were asked to rate the importance of all items on a Lickert scale from 1 to 5. Since the objective of the survey is to measure how foreign business people feel about or perceive the on-going changes in Korea's business environment, a scale measurement is appropriate (Neuman 2000: 180). Out of five-point interval scales, respondents showed their degree of agreement with the statement (question), where scale one (1) indicates least agreeable, and scale five (5) shows most agreeable. Since the midpoint (3) means neutral, an average score equal to or greater than 3 is regarded as agreeable.

As shown in Table 1, foreign perceptions are in general significantly different from those held by domestic workers for 17 out of 25 items at the 0.01 level of significance and 20 out of 25 items at the 0.05 level. ${ }^{\mathrm{vi}}$ The results of the first two questions in Table 1 indicate that both foreign and domestic business people agreed with 'optimistic economic prospects' and 'disappearance of the lifetime employment practice', although the extent of their agreement were significantly different. According to the third question, both groups agreed, to a similar extent, on Korean workers' 'willingness to train for new jobs'. For the next two items in Table 1, the views were all significantly different between the two groups. While foreign business people agreed on the 'improving political stability in Korea' and also on the existence of a 'highly collaborative team spirit' among Korean workers, their domestic counterparts disagreed. In contrast, for the next 12 questions that 
are related to Korean management practices, foreigners had all negative views on them, while their domestic counterparts had positive views. And their differences are all significant, except for one item (Korean workers as highly skilled and efficient workers). The responses for the next two items indicated that both groups had negative views on declining union militancy, cronyism and corruption, although the extents of their negative views were significantly different. For the remaining six questions related to political risk, government regulations, and some managerial aspects, both groups had similarly negative views on improvement in these aspects. In view of significant differences in perceptions for 17 out of 25 spheres of the Korean business environment at the 0.01 level of significance, it is warranted to treat the perceptions held by foreign business people separately from those held by the domestic counterparts, as has been done in this study. The following results are limited to the perceptions held by foreign business people in Korea, as these directly relate to the image of Korea as a country suitable for investment.

\section{Insert Table 1}

\subsection{Improvement in Korea's business environment since 1997}

The questionnaire distributed only to foreign business people included 17 questions to identify specific improvements, if any, in the Korean business environment as perceived by foreign business people. Each of these questions and its rating are shown in Table 2. Foreign business people had in general a moderately negative view on improvement in Korea's business environment, as indicated by an overall average rating of 2.725 .

With regard to improvements in the areas related to political risk and governmentbusiness relations, respondents expressed negative opinions on all possible improvements except 'political stability'. They considered that 'political stability' had improved 
moderately in Korea with a mean score of 3.333. However, 'North-South Korean relations' were not seen to have improved, as indicated by a mean score of 2.726. Foreign business people did not consider that 'transparency and consistency in government regulations' had improved considerably, with a mean score of 2.841. Nor did they think 'government regulations and interference' and 'cronyism and corruption' had improved considerably with mean scores of 2.797 and 2.594 respectively. Respondents also indicated their belief that 'protection of intellectual property rights' had not improved, with a score of 2.565. They also generally held the view that 'regulations on the real estate market' and 'distribution system' had not improved.

Insert Table 2

Interviews with survey participants revealed a view that there was substantial inconsistency in the policies, regulations and administrative procedures between the central and local governments. Some foreign expatriates voiced their concern at the opacity and variability in interpreting and applying regulations at the local government level. They were also aggrieved by inter-authority turf wars between fire, police, construction, and environmental authorities at both local and regional levels, since these battles delay approval requirements.

In terms of business prospects and business relations with Korean companies, respondents were quite optimistic about the improvement of Korean 'economic prospects', with a mean score of 3.746. However, they had negative views on improvements in their business relations with Korean companies. Views on improvements in Korean companies 'becoming better business partners' or 'engaging in level-field competition' were moderately negative, with mean scores, respectively, of 2.820 and 
2.524. It is instructive to note that foreign business people did not consider that the 'importance of personal relationships in daily business operations' had declined, as indicated by a mean score of 2.274. This runs counter to an intuitive perception of many business people in Korea that the Korean management system has of necessity shifted substantially toward the western system that stresses rationality over personal relationships. The view among respondents that the personal relationship continues to be important in business operations in Korea supports the long-held belief that cultures die hard.

Foreign business expatriates expressed negative views on the issue of improving labour relations. They had a negative, though moderate, view about Korea becoming a country where it is 'easier to hire and retain local workers', with a mean score of 2.672. They disagreed that 'dismissing Korean workers' was becoming easier, with a mean score of 2.435. Likewise, they strongly disagreed with the statement on 'declining union militancy' with a mean score of 2.410, suggesting strongly that union militancy remains one of the major difficulties in on-site management. Through personal interviews, survey participants expressed strong negative feelings about the inflexibility of Korean workers and militant unions.

Foreign business people expressed their negative views, though moderate, that discrimination in Korean society against foreign products had improved as indicated by a mean score of 2.887. Nor did foreigners consider that their cultural and communication difficulties had improved with a mean score of 2.714. In personal interviews, many participants expressed the view that Koreans were still nationalistic and narrow-minded and did not appreciate racial diversity in the world as a matter of fact. They also considered that Koreans did not accept well inter-racial marriages and mixed-race children. A number of participants commented that non-Korean products were not readily 
available, and that Korea needed more restaurants with foreign and varied menus. Some participants also spoke of conflicts they experienced with Korean partners and other Koreans, as a result of a lack of understanding of each other's cultures and institutions.

\subsection{Management of on-site operations in Korea}

The survey questionnaire included 19 questions designed to identify difficulties encountered in operating and managing businesses in Korea. The results were consistent with the negative views, mentioned above, concerning improvements in the Korean business environment. As shown in Table 3, most of the difficulties rated quite highly, with an overall average score of 3.186. It should also be noted that a major portion of the difficulties in on-site management are related to Korean companies, market forces or social and cultural matters, which are beyond government control in the more liberalised market.

\section{Insert Table 3}

In the area of government-business relations, 'lack of transparency and consistency in regulations', 'prevailing cronyism and corruption', 'excessive discretionary power of bureaucrats', and 'excessive government regulations' were all regarded as difficult areas, with mean scores ranging from 3.516 to 3.836. The 'tax system' and 'poor social overhead capital (infrastructure)’ were not regarded as seriously difficult areas.

On their business operations, respondents rated 'importance of personal relationships in business' as the most arduous challenge with a mean score of 3.836. Their views on the importance of personal relationships in Korea led them to consider themselves disadvantaged. As indicated above, this is quite different from the prevailing perception among Korean business people that Korean management is moving toward western management in which personal relationships have much less bearing on business 
operation. Respondents also rated highly 'unfair advantages held by Korean firms especially chaebols' as another difficult challenge with a mean score of 3.651. 'High overhead costs (rent, insurance, utilities)' were not considered a difficult area with a mean score of 2.967. Other types of difficulties in relation to Korean business were not considered as serious, including 'entry into the Korean distribution system', 'conflicts with Korean partners', and 'getting parts and materials', with mean scores ranging from 2.183 to 2.790 .

In the area of human resource management, 'recruiting and retaining efficient local workers' was regarded as the most difficult task with a mean score of 3.066. This is consistent with the views discussed above, indicating that respondents saw human resources as an area that had not improved in recent years. 'High wage levels and low labour productivity' were also regarded as an area of concern, with a mean score of 3.048. 'Militant unions' were not regarded as part of the major management difficulties with a score of 2.767, even though, as indicated above, respondents claimed that union militancy had not improved. This perception appears to be attributable to the majority of the responding companies coming from the service sector where unions are typically less militant.

Foreign business people considered that coping with culture and society was difficult for them and, as indicated above, they felt that circumstances had not improved significantly for them in recent times. 'Cultural and communication differences' was ranked highest with a score of 3.597. They noted that Koreans had some prejudices against foreign firms and products with a score of 3.371, and that Korean society was largely closed to foreigners, with a score of 3.333. Finally, many respondents regarded poor social amenities for expatriate families as a serious concern, with a score of 3.117.

\subsection{Respondents' Views of Korean Firms (Chaebols)}


The questionnaire asked six questions to identify how foreign respondents perceived recent changes in chaebols as their business counterparts. As shown in Table 4, foreign business people had negative views on the improvement of chaebols as indicated by an overall average score of 2.501. Related to chaebol reform, foreign respondents did not consider that 'corporate governance' and 'operational transparency' had improved, as indicated by the mean scores of 2.525 and 2.468 respectively.

Insert Table 4

It appears that foreign business people view chaebols as adversarial competitors. They did not consider chaebols as 'becoming more efficient recently' with a mean score of 2.844. They did not view the chaebols' dominance in Korean business as declining, nor did they view chaebols as becoming more cooperative business partners. In particular, they did not think that chaebols were competing on a level-playing field.

\subsection{Respondents' Views of Korean Workers}

The questionnaire included 10 questions related to foreigners' perceptions of Korean workers. Seven questions asked about the positive aspects of Korean workers, and the remaining three asked about the negative aspects of Korean workers. Foreign business people agreed strongly with positive aspects with an overall average score of 3.297. They disagreed marginally with the negative aspects, with an overall average score of 2.958 (Table 5).

Insert Table 5 
The average scores for five of the seven questions that asked about the positive characteristics of Korean workers were higher than 3.0. Of the seven questions, the highest score of 3.656 was given to the statement that Korean workers were 'willing to work for foreign companies'. This shows a significant change in the mind-set of Korean workers, as their earlier preference was to work for domestic companies. Korean workers have a reputation as hard working people, and this was reflected in a high score of 3.594 for the response to 'hard working'. Foreign business people also agreed with other positive aspects of Korean workers, such as being 'highly loyal to their companies and supervisors', having a 'highly collaborative team spirit', and being 'willing to be trained for new jobs'. However, foreigners did not consider Korean workers as being 'highly skilled and efficient', nor possessing 'high reliability and stability' with the mean scores of 2.923 and 2.815 respectively. Overall, however, these survey findings confirm the reputable nature of Korean workers.

Foreign respondents disagreed, although marginally, with the negative aspects of Korean workers, with an overall average score of 2.958. Poor English language skills were rated as the most serious issue, with an average score of 3.281. 'Highly unionised and militant' characteristics of Korean workers were not too serious a concern, as indicated by a score of 2.826. This is consistent with the view of foreign expatriates that, as pointed out earlier, while militant unions are a concern, they are not a serious issue for on-site management. Finally, foreigners disagreed, although modestly, with the idea that Korean workers ‘change jobs frequently', with a mean score of 2.766 (Table 5).

\subsection{Respondents’ Views of Changes in the Korean Management System}

It has been argued that the Korean management system has changed considerably toward the western system since the financial crisis in 1997. To assess the perceptions of changes in the Korean management system held by foreign business people, the questionnaire 
included 12 questions that asked their views on changes in various aspects of the management system such as: the objectives of firms, decision-making process, organisation, leadership, human resource management, overall management efficiency, and overall change.

Respondents had an overall negative view of change in the Korean management system as indicated by an overall average score of 2.686 for the 12 types of possible changes included in the questionnaire (Table 6). Of these 12 possible types of changes in Korean management, Korean companies developing 'more profit-oriented management' was rated most highly, with an average rating of 3.349. This finding suggests that Korean firms are moving from their traditional business objectives of maximum growth or maximum market share toward profit maximisation, as is generally the case for western firms. 'Decreasing layers in the hierarchical organisational structure' was rated at a mean score of 2.591, suggesting that in the view of foreign business people, the hierarchical layers in the organisational structure of Korean companies are not decreasing significantly. Consistently, the findings also indicate that the top-down, authoritarian decision-making system is not changing to a considerable extent, as indicated by a low mean score of 2.262. Finally, a mean score of 2.594 for ‘fading paternalistic leadership’ indicates that from the viewpoint of foreign business people, the paternalistic style of leadership is not really fading in Korean management.

\section{Insert Table 6}

Respondents were generally of the view that human resource management in Korea had changed little. The average score on six types of possible changes in human resource management was 2.730 (Table 6). Of those six types of changes, two aspects were rated higher than 3.0, while four were rated less than 3.0. Foreigners generally 
agreed with the view that 'lifetime employment practices are disappearing' with a score of 3.156, and marginally agreed with the view that the 'lay-off of workers is increasing', with a score of 3.032. Respondents appeared to disagree that changes were made towards 'merit-based promotion and compensation', 'recruitment by merit' and 'disappearance of seniority system', which were rated, respectively, at 2.615, 2.462 and 2.394. They also disagreed, although marginally, that change was evident in Korean companies’ 'willingness to hire foreign workers'. This indicates a perception that, although lifetime employment practices are disappearing, other conventional human resource management practices are changing little.

Finally, respondents disagreed marginally that the overall efficiency of Korean management had improved, and that the Korean management system was becoming similar to their own system. The average rating for the former was 2.734 and for the latter was 2.328 (Table 6). The survey findings suggest that from the perspective of foreign expatriates in Korea the Korean management system remains more or less unchanged, except that it is becoming more profit oriented and that lifetime employment is disappearing.

\subsection{Respondents' Views of Expatriates’ Living Conditions in Korea}

The survey questionnaire included a set of questions, seeking to identify views about some improvements, if any, in the living conditions of foreign expatriates. As shown in Table 7, foreign expatriates had strong negative opinions on improvements in their living conditions in Korea, as indicated by an overall average rate of 2.192 for the seven possible types of improvements. They viewed that 'social amenities' had improved marginally, as indicated by a mean score of 3.015, while they disagreed marginally with the statement that Koreans' 'prejudice against foreigners' had weakened, as indicated by a mean score of 2.765. However, the remaining types of improvement in living conditions, such as 
‘improving overall living costs', 'reasonable rent and real estate prices’, ‘improving environmental pollution', and ‘declining traffic congestion’ were all rated quite low, ranging from 1.735 to 2.154 . These results suggest that in the view of foreign expatriates, the cost of living in Korea, including rent and education costs, remains high, and environmental pollution and traffic congestion are not improving. These findings also suggest that in its bid to improve the business environment, the government should pay more attention to improving the living conditions of foreign expatriates.

\section{Insert Table 7}

\section{Discussion}

This paper is an attempt to provide some evidence of recent changes in the Korean business environment as perceived by foreign business people in Korea. Prior to the 1997 financial crisis, Korea was regarded as one of the most difficult places to do business by the international business community. Since 1997, the government has undertaken a metamorphosis in economic policy, internationalising and liberalising the economy and at the same time attempting to improve the Korean business environment. The private sector and Korean society have also changed, becoming more amicable to foreign business operations in Korea. Despite these developments in the recent past, there is little concrete evidence to suggest that Korea’s business environment has actually improved. No empirical study that has attempted to identify specific changes in the Korean business environment is available in the literature. In particular, despite the importance of foreign perspectives in discarding Korea's unwanted reputation as a difficult place to do business, and in establishing a new image as an attractive country for foreign businesses, the Korean business environment and recent changes thereof have not been assessed from a foreign perspective. 
A comprehensive survey was conducted in 2002 of foreign companies that had undertaken direct investment in Korea and were operating businesses in Korea. Two forms of questionnaires were developed. The first one which was the main and comprehensive one was distributed to foreign business people working in Korea. The second questionnaire was developed in Korean with a set of questions selected from the first questionnaire. The second questionnaire, distributed to Korean companies, was to identify differences in perception between foreign and Korean business people in Korea on mutually relevant aspects of the Korean business environment. From surveys of both foreign business people and their Korean counterparts with the same set of questions, it was found that perceptions of the Korean business environment held by the former were in general significantly different from those held by the latter. It is thus warranted to treat the perceptions held by the two groups separately, as has been done in this study.

According to the survey results, foreign business people have in general a negative view on progress in improving the Korean business environment in the recent past, except regarding enhanced domestic political stability and economic prospects. In particular, they consider that government-business relations have not really improved, and view progress in improving labour relations highly negatively. According to the view of foreign business people, neither Koreans’ discrimination against foreign products, nor foreigners’ cultural and communication difficulties have been significantly alleviated.

Consistent with their negative views on improvements in the business environment in the recent past, foreign business people point to various types of difficulties in the management of on-site operations, such as a lack of transparency and consistency in the excessive government regulations, cronyism and corruption, and the excessive discretionary power of bureaucrats. Foreign companies consider themselves disadvantaged in a system where Korean firms rely heavily on personal relationships for business 
operations. The areas of human resource management and labour relations are also identified as problem areas. Other serious difficulties identified by foreigners include cultural and communication difficulties, Koreans' prejudice against foreign products, the closed Korean society and poor social amenities for expatriate families.

The survey results also show that foreign business people do not consider that corporate governance and the operational transparency of chaebols have improved significantly. Chaebols are still regarded as adversarial competitors with various types of unfair advantages. Except for limited aspects of management such as more profit-oriented management, disappearing lifetime employment, and rising lay-offs of workers, foreigners consider that the Korean management system remains largely unchanged. The survey findings confirm the reputable characteristics of Korean workers. Korean workers’ willingness to work for foreign companies, diligence, loyalty toward companies, collaborative team spirit, and willingness to be trained are all highly regarded. Poor English skills are regarded as the weakest aspect of Korean workers.

As an exploratory study applying a number of spheres of business environments identified in literature on the international business environment, FDI, management and human resource management, the present study does not seek to theorise the relative effects of each sphere on the Korean business environment. The contribution of this study is empirical in nature. The study provides an empirical evidence of the existence of differences in perception of Korea's business environment between foreign business people and their Korean counterparts. It also identifies negative views of foreign business people on improvements in the Korean business environment in the recent past and various types of existing difficulties in operating business in Korea.

\section{Implications}


The present study provides important warning signals for multinational firms that are doing business in Korea or are planning to do so. Even though Korea has liberalised its formal entry barriers to a level on a par with most other OECD countries (Bishop 2001), and undertaken institutional and structural reforms of the economy, foreign firms will still face various challenges in entering and operating in Korea. In particular, findings of the present study point to a number of specific areas for which foreign firms and investors should pay attention and prepare themselves in undertaking business in Korea.

For Korea in its endeavour to improve the business environment and to attract foreign direct investment, the present study shows that in spite of some improvements in the business environment in the recent past there is substantial room for improvement in numerous aspects. Not only should the Korean government continue across-the-board liberalisation of the economy, but it should also improve the operational environment of business, particularly in those spheres identified by the present study. The present study also provides a strong message to Koreans that they have to change their mind-sets to be more compatible with the globalisation trend.

The challenges confronting foreign firms that have been examined in this study are the perceptions of survey respondents. The people of Korea may disagree profoundly with the respondents' claims. Nevertheless, since the respondents have first-hand experience of the Korean business environment, and it is these types of investors that the Korean government is trying to attract, the survey findings of this study point to a number of areas that government policy should reconsider in its bid to establish a new reputation of Korea as a country attractive to foreign businesses.

Findings of the present study point to a number of areas for future research. A factor analysis can be undertaken to combine a number of related spheres of the Korean business environment, thereby reducing the number of questions in the questionnaire and 
in turn increasing the survey response rate. Since the extents of internationalisation and liberalisation are different by industry in Korea, an industrial analysis of foreigners’ perception of the Korean business environment will be useful. Finally, since cultural and communication difficulties remain serious, an analysis of the perceptions of Korea's business environment by country origin of foreign business people will provide useful information, although such an analysis is contingent on a decent survey response rate across home countries of foreigners which is in turn a challenging task.

\section{Conclusion}

This study provides an empirical evidence that, in spite of the efforts by the Korean government and society to improve the business environment in the wake of the 1997 financial crisis, foreign business people in Korea hold in general a negative view on progress in its improvement. They consider that the major spheres of business environments including government-business relations, labour relations, business relations with Korean counterparts, and Koreans’ parochial attitudes have not really improved. They then point to various types of existing difficulties in entering and operating business in Korea.

Findings of the present study provide important warning signals for foreign firms that are planning to enter and conduct business in Korea, and identify a number of specific areas for which they should pay attention and prepare themselves. The present study also provides a strong message to Korea that, in spite of some improvement in its business environment in the recent past, it should further improve in numerous aspects of it to establish a new reputation for Korea as a country attractive to foreign businesses. Even if the Korean government and its people disagree with the perceptions of the Korean business environment held by foreign business people, Korea has to pay heed to their 
claims. They are the types of people Korea is trying to attract, and the Korean government must consider seriously those problematic areas they have pointed out through this study.

\section{Acknowledgements}

The author gratefully acknowledges the valuable comments and suggestions from three anonymous reviewers during the review process.

\section{References}

American Chamber of Commerce in Korea (2002) Improving Korea's Business Climate 2002, Seoul, Korea: American Chamber of Commerce in Korea.

Ball, D.A., McCulloch, W.H., Frantz, P.L., Geringer, J.M., and Minor, M.S. (2002), International Business: The Challenge of Global Competition, $8^{\text {th }}$ edition, Boston, McGraw-Hill Irwin.

Beeson, Mark (2002) 'Conclusion: the more things change ...? Path dependency and conversion in East Asia', in Mark Beeson (ed.) Reconfiguring East Asia: Regional Institutions and Organisations after the Crisis, London, RoutledgeCurzon: 247-257.

Bishop, B. (2001) 'The liberalization of foreign direct investment policy in Korea', in O.Y. Kwon and W. Shepherd (eds.) Korea's Economic Prospects: From Financial Crisis to Prosperity, Cheltenham, UK: Edward Elgar, pp. 266-280.

Bishop, B.(2003) 'Will East Asia follow Korea’s lead in liberalizing foreign direct investment Policy?’, in O.Y. Kwon, S.H. Jwa, and K.T.Lee (eds.) Korea's New Economic Strategy in the Globalisation, Cheltenham, UK: Edward Elgar, pp. 98112.

Booz.Allen \& Hamilton (1997) Revitalizing the Korean Economy toward the $21^{\text {st }}$ Century, Booz.Allen \& Hamilton, Seoul, Korea.

Cha, Dong-Se (2001) 'The Korean economy in the new millennium: reform or revival?' in in O.Y. Kwon and W. Shepherd (eds.) Korea's Economic Prospects: From Financial Crisis to Prosperity, Cheltenham, UK: Edward Elgar, pp. 39-59.

Chang, C.S. and Chang N.J. (1994) The Korean Management System, London: Quorum Books.

Cho, Yun-Ho and Yoon, J.K. (2002)‘The origin and function of dynamic collectivism: an analysis of Korean corporate culture', in Chris Rowley, T.W. Sohn, and J. S. Bae 
(eds.) Managing Korean Business: Organization, Culture, Human Resources and Change, Southgate, London: Frank Cass Publishers, pp. 70-88.

Dunning, J.H. (2000) 'The eclectic paradigm as an envelope for economic and business theories of MNE activity', International Business Review, 9, pp. 163-190.

European Union Chamber of Commerce in Korea (2002) Trade Issues \& Recommendations, 2002, Seoul, Korea: European Union Chamber of Commerce in Korea.

Far Eastern Economic Review (1998) ‘Asian executives poll’, Far Eastern Economic Review, 18 (June).

Frankfort-Nachmias, C. and Nachmias D. (1996) Research Methods in the Social Sciences, $5^{\text {th }}$ ed. London: Arnold.

Hill. C.W.L. (2005) International Business, $5^{\text {th }}$ edition, New York: McGraw-Hill Irwin.

Jwa, Sung Hee and Yi, Insill (2001) 'Korea financial crisis: evaluation and lessons' in O.Y. Kwon and W. Shepherd, (eds.) Korea's Economic Prospects: From Financial Crisis to Prosperity, Cheltenham, UK: Edward Elgar Publishing, pp. 7398.

Kim, June-Dong (2003) Inward Foreign Direct Investment into Korea: Recent Performance and Future Agenda, Discussion Paper 03-01, Korea Institute for International Economic Policy, Seoul, Korea.

Kim, Wan-Soon and Choo, M.J. (2002) Managing the Road to Globalization:" the Korean Experience, Seoul: Korea Trade \& Investment Promotion Agency (KOTRA).

Kwon, O. Yul (1998) 'The Korean financial crisis: diagnosis, remedies and prospects', Journal of the Asia Pacific Economy, vol. 3, no. 3, pp. 331-57.

Kwon, O. Yul (2001a) 'Paradigm shift in Korean economic policy in the wake of the 1997 financial crisis and future policy directions', in Chowdhury A. and I. Islam (eds.) Beyond the Asian Crisis, Cheltenham: Edward Elgar, pp. 75-100..

Kwon, O. Yul (2001b) 'Korea's international business environment before and after the financial crisis’, in O.Y. Kwon and W. Shepherd, (eds.) Korea’s Economic Prospects: From Financial Crisis to Prosperity, Cheltenham, UK: Edward Elgar Publishing, pp. 245-265.

Lee, Hak Chong (1989) 'Managerial characteristics of Korean firms', in K.H. Chung and H.C. Lee (eds.) Korean Managerial Dynamics, New York: Praeger Publishers.

Lee, Jaymin (2003) 'Economic crisis and structural reform in Korea', in C.H. Sohn (ed.) Structural Reforms and Economic Development, Seoul: Korea Institute for International Economic Policy, pp. 35-64. 
Lee, K.T., Choi, N.G. and Kang, J.G. (2003) 'Korea's foreign trade strategy in the new millennium', in O.Y. Kwon, S.H. Jwa, and K.T.Lee (eds.) Korea's New Economic Strategy in the Globalisation, Cheltenham, UK: Edward Elgar, pp. 50-62.

Neuman, W.L. (2000) Social Research Methods: Qualitative and Quantitative Approaches , 4th ed, Boston: Allyn and Bacon.

North, Douglas C. (1990), Institutions, Institutional Change and Economic Performance, Cambridge: Cambridge University Press.

Oh, Ingyu and Park, H.J. (2002) 'Shooting at a moving target: four theoretical problems in explaining the dynamics of the chaebol', in Chris Rowley, T.W. Sohn, and J. S. Bae (eds.) Managing Korean Business: Organization, Culture, Human Resources and Change, Southgate, London: Rank Cass Publishers, pp. 44-69.

Park, Won-Woo (2002), 'The corporate culture change campaigns in Korea: lessons from their failures', in Chris Rowley, T.W. Sohn, and J. S. Bae (eds.) Managing Korean Business: Organization, Culture, Human Resources and Change, Southgate, London: Rank Cass Publishers, pp. 89-110.

Pearce, J.A. II and R.B. Robinson, Jr (1994), Strategic Management: Formulation, Implementation, and Control, Burr Ridge, Ill: Irwin.

Rowley, Chris (2001), 'South Korean management in transition', in M. Warner and P. Joynt (eds.) Managing Across Cultures: Issues and Perspectives, Sydney: Tomson \& Learning.

Shim, Won-Shul and Steers, Richard M. (2002), 'The entrepreneurial basis of Korean enterprise: past accomplishments and future challenges' in Chris Rowley, T.W. Sohn, and J. S. Bae (eds.) Managing Korean Business: Organization, Culture, Human Resources and Change, Southgate, London: Rank Cass Publishers, 22-43.

Whitley, Richard (1998), 'Internationalization and varieties of capitalism: the limited effects of cross-national coordination of economic activities on the nature of business systems', Review of International Political Economy, 5(3): 445-481.

Yin, R.K. (1984), Case Study Research: Design and Methods, Beverley Hills: Sage Publication.

\footnotetext{
${ }^{\text {i }}$ A number of studies have argued that Korea's business environment has improved since the 1997 financial crisis without providing convincing evidence. See, for example, Bishop (2001, 2003), Kim (2003), Kim and
} 
Choo (2002), Kwon (2001b), Lee (2003), and Lee, Choi and Kang (2003). Besides, none of these studies has attempted to address foreign perspectives of Korea's business environment.

ii There are some studies of Korea's business environment by foreign Chambers of Commerce in Korea such as the American Chamber of Commerce in Korea (2002) and the European Union Chamber of Commerce in Korea (2002). However, these reports are not well theoretically underpinned, nor are their methodologies fully specified. Besides, foreign Chambers are kinds of lobbyists for their own countries' business, rather than being objective analysts of Korea's business environment. One would get an impression from these reports that they are collections of grievances of their members with a touch of hyperbole. Beyond these, no study in this respect is available in the literature to the best of the author's knowledge.

iii For the concept of exploratory studies, see Neuman (2000:21).

iv This is a way of enhancing validity of the questions in the questionnaire (Frankfort-Nachmias and Nachmias 1996: 168; Neuman 2000: 167). In measuring and comparing business environments among countries, the Economist Intelligence Unit (EIU) uses six indicators: market potential, tax and labour market policies, infrastructures, skills and political stability (Ball et al 2002: 641). The EIU indicators are all included in the questionnaire of this study.

${ }^{v}$ These are tactics to enhance validity of the data (Yin 1984).

${ }^{\text {vi }}$ It should be noted that the responses of foreign business people in Korea would have a negative bias since such a survey could be regarded by them as an instrument to appeal to Korean policy makers to improve the business environment. Attempts have been made to minimize such a bias through the covering letter, pilot surveys and personal interviews with some of the respondents. 